look at other fields of endeavour and see their relation to the main cause of study, and also the value of making it easy to change from the arts to the science side, or vice versa, later than the usual age of fourteen. In the discussion, Prof. J. L. Montrose, while welcoming much of Mr. Lee's address, dissented emphatically from the view that general education could only be given at school, suggesting that it comes late in a university career, even in postgraduate study, and in this he was supported by Dr. F. M. Brewer. Mr. S. R. Woods referred to the need for some method of assessing general education, and Dr. G. N. Burkhardt suggested that specialist study in the sixth form would be reduced if the syllabuses on which Advanced Level and Scholarship papers of the General Certificate of Education are set were reduced to two-thirds of their present size. This idea of pruning was supported by Mr. Lee and Miss Anderson; but Miss Anderson did not believe that general education could be examined.

Dr. V. E. Cosslett's paper on the financing of research in universities by outside bodies was read, in his absence through illness, by the chairman, Prof. J. L. Montrose. Basing his remarks on a recent investigation of the Association of University Teachers, Dr. Cosslett said that about 20 per cent of the research resources of university departments of science and technology are engaged on work of direct interest to industry and that about 5 per cent of university income is derived from industrial support for research. Grants-from charitable foundations and learned societies provide a further 2 per cent, and research grants from government sources amount to about 7 per cent of university income. Dr. Cosslett raised the questions whether limits should be set to the amount of outside grants received by a university and to the proportion of sponsored research within this amount, and, if so, what principles should guide the universities in discriminating between grants. He suggested a limit of 50 per cent for outside grants and that not more than 50 per cent, preferably not more than 30-35 per cent, of research projects in a department should be sponsored projects.

Prof. H. W. Melville, who followed, dealt more particularly with the functions of the Department of Scientific and Industrial Research and the connexion between university scientists and government defence establishments; but he also commented on the relations with private industry, which is likely to become the largest contributor to the support of university research, and stressed the value of second. ing industrial personnel to work in a university. Sir Harold Himsworth, who dealt largely with medical research, put the government contribution to university research at about $£ 3$ million, of which $£ 1 \cdot 17$ million is from the Medical Research Council. He thought the device of establishing research units in association with universities has proved an elastic and effective way of dealing with special problems of common interest, but that there is a natural tendency for successful units to be taken over by university departments. Government support of research by non-academic bodies is, however, increasing and is likely to increase further. Sir William Slater was in general agreement with Sir Harold's remarks, as was Prof. A. R. J. P. Ubbelohde, who discounted some of Dr. Cosslett's statistics. Prof. N. F. Mott also did not share Dr. Cosslett's concern about support from industry, and Prof. J. A. Pope challenged the adequacy of the grants for postgraduate work by the Department of Scientific and Industrial Research.

\section{NATIONAL FOUNDATION FOR SCIENTIFIC RESEARCH, BRUSSELS}

\section{REPORT FOR 1954-55}

$B^{\mathrm{E}}$

ESIDES the lists of recipients of grants for 1955-56 and the subjects of research, the eighteenth annual report of the National Foundation for Scientific Research, Brussels, covering the year 1954-55*, includes an inventory of microfilms and a list of publications by recipients of grants during the year under review. The Special Commission for Clinical Research received subsidies of 345,000 francs for the work at the University of Brussels on the effect of suprarenal-cortico hormones on the renal reabsorption of proteins, on the effect of suprarenal hormones on the metabolism of fructose in normal subjects, diabetics and patients suffering from hepatic deficiency, and on the inhibiting effect of plasmatic hypertony on the liberation of hormones of the suprarenal cortex provoked by a standard dose of adrenocorticotropic hormone; other work reported relates to the depressive action of cortisone on thyroid activity and to human suprarenalectomy. A grant of 350,000 francs for the State University of Ghent was for work on the influence of cortisone on the respiration of cardiac and diaphragmatic tissues, the stimulation of the suprarenal cortex by adrenocorticotropic hormone, the effects of the latter and cortisone on lipoproteins and the hydrolysis of corticoid urinary reducers. The State University of Liège received a subsidy of 520,000 francs for a comparative pharmacodynamic study of the effects on the organism of the injection of sodium salicylate and other compounds, and the Catholic University of Louvain 456,000 francs for its work on the hormonal inter-relations during gestation.

Grants to research workers for 1955-56 totalled $3,515,000$ francs, while for the years 1956 and 1957 a total of $3,000,000$ francs was allocated to the National Centre of Aeronautical Studies and Research. The first electronic calculating machine designed and constructed in Belgium was completed in Antwerp in February 1955. A special credit of 200,000 francs was made to enable $M$. Velghe to complete his astronomical work at the Boyden station of Harvard University at Bloemfontein in South Africa. Prof. M. de Hemptinne and M. Migeotte received a grant of 135,000 francs for their infra-red spectroscopical work, and Prof. J. Morelle, Ch. De Muylder and P. De Temmerman received 150,000 francs for their research on experimental coarctation and its retention and on vascular peripheral resistance.

Radioisotopes distributed in Belgium under the authority of the Foundation have been used in the following proportions: medicine, 31 ; industry, 25 ; agriculture, 6 ; physics, chemistry, biochemistry and applied sciences, 28 ; public services, 5 . At the University of Brussels, the exchange of calcium between the bony tissues and the general organism has been studied in the dog with calcium-45; and the isotope phosphorus-32 has been used to study certain aspects of the dispersion of organic phosphorus compounds in the organism and their fixation on cholinesterase, the anti-cholinesterase activity in

* Fonds National de la Recherche Scientifique. Vingt-huitième Rapport Annuel, 1954-55. Pp. 269. (Bruxelles : Fonds National de la Recherche Scientifique, 1956.) 
certain organo-phosphorus insecticides, including the synthesis of diisopropyl chlorophosphate and diisopropyl fluorophosphate, and the assimilation of carbon dioxide by micro-organisms by means of carbon-14 dioxide. At the University of Ghent the isotope zinc-65 has been used for establishing the distribution constants of zine bromide in liquid-liquid extraction with diethyl ether and diisopropyl ether, carbon-14 has been used to study the influence of dinitrocyclopentylphenol on the metabolism of alcohol in mice, and radioactive iodine has been used for study ing the metabolism of iodine in infants suffering from lipoid nephrosis. At the University of Liège, carbon-14 has been utilized for preparing methyl iodide and L-methionine in studying the biological origin of the methyl group of adrenaline and of creatine ; iodine-131 has been used for studying a number of toxic goitres, phosphorus-32 for studying the role of inhibitors of cholinesterase on the penetration of the phosphate ion in respiratory organs of the mussel, and carbon-14 for examining the metabolism of cstrone in the rabbit.

At the University of Louvain rubidium- 86 has been used in studies of the beta-gamma angular correlation of this element, carbon-14 in studies of the decomposition of organic matter in the soil, and at the Royal Military School various studies, by means of chlorine-36 and iodine-131, have been made of heterogeneous reactions in the gaseous phase. At the State Agronomic Institute at Gembloux phosphorus-32 has been used in research on its eventual toxic effect on the development of the mycelium of mushrooms and in the chemical separation of phosphorus compounds such as phospholipoids, nucleoproteins, mineral compounds soluble in water and mineral compounds soluble in acids. In clinical work, gold-198 was utilized in three cases at the Centre for Tumours and Physical Medicine, iodine131 in the treatment of thyrotoxicosis, while in industry iridium-192, cobalt-60 and cæsium-137 have been applied in the radiography of steel and in the detection of welding faults, and thallium-204 has been used in experiments on the elimination of static charges.

\section{THE AFRICAN WILD DOG}

$\mathrm{T}$ HE African wild dog, or hunting dog, Lycaon pictus, is a distinct species and is neither related to any domestic breed nor does it appear to be the forerunner of any known type of domestic dog: there are certain structural differences, such as the absence of dew-claws. According to R. M. Bere, the dogs stand about twenty-six inches at the shoulder and measure about four feet from nose to tip of bushy tail (Oryx, 3, No. 4; May 1956). The colour is variable, but is similar to that of a normal 'Alsatian' (German shepherd dog), the animal being covered to a greater or lesser degree with black, yellow or white blotches. A notable feature is the large upstanding, rounded ears. There are recorded cases of wild dogs having been successfully tamed; but an objectionable smell renders them somewhat unpleasant as household pets.

Wild dogs hunt in packs, killing wantonly far more than they need for food, and by methods of the utmost cruelty : Lycaon does not kill quickly as the lion does, but often starts to devour his antelope victim bofore life is extinct. They do more damage than almost any other of the Carnivorae; when they enter a particular stretch of country the dis. turbance they cause is so great that, for the time being, all the buck are driven out. The absence of antelope from an area is often the first sign of the wild dogs' presence. A particularly unpleasant characteristic is that they will, without hesitation, turn upon any member of the pack that falls by the way through wound or sickness and show no reluctance to consume their own kind.

When the Uganda National Parks were established it was considered necessary, as had been the case elsewhere, to shoot wild dogs in order to give the antelope opportunity to develop their optimum numbers. Fortunately, only a few wild dogs have had to be destroyed, and their number in the parks does not seem to be particularly large. Their habits do not allow them to stay for long in any one place, for they would starve if they did so : the wild dog packs create their havoc and move on.

The shooting of wild dogs has been questioned recently on the ground that, if persisted in, it would result in a disturbance of the balance of Nature. It was argued that should the antelope increase beyond a reasonable limit, the inevitable result would be starvation due to over-stocking and over-grazing. On balance it appears clear that, provided the packs do not increase beyond a reasonable size, they should not be interfered with. With wild animals generally, the rate of breeding and the percentage of those born to reach maturity is, in the absence of predators, largely controlled by the food supply. Generally speaking, the infant mortality among the Carnivorae seems relatively high, so that unless the food supply becomes abnormally easy, numbers just about maintain themselves.

\section{THE SWEDISH FOREST SERVICE}

$\mathrm{T}$ HE forests of Sweden have played almost as important a part in Britain as in Sweden itself during the last half of the nineteenth century and the first half of the present, and it is not inappropriate, therefore, that the Swedish Forest Service should have published in English a handsome booklet on the development of the forests in relation to the Service*. It was the change in materials used for construction in Britain, especially for ships and buildings, which gave rise to a large demand for coniferous timbers, and Sweden seized the opportunity to exploit its large areas of coniferous virgin forests; until then the chief commercial home demand was for charcoal for the mineral industry. Swedish exports to Britain largely increased after the latter took off the import duty on softwoods in 1866 . In fact, with its increasing industrial activity and increasing demands for pit wood for the coal mines, building timbers and paper pulp, Britain was lulled into a false sense of security; plans for starting afforestation in Britain, the subject of royal commissions, committees, etc., came to nothing, and by the end of the nineteenth century Sweden had built up a very prosperous export trade.

The early history of Swedish forests, though on a much larger scale, was similar to that of Britain to a great extent. In early times the king owned large areas, which were used for hunting purposes, and claimed all waste land. Then came a period in the

* The Swedish Forest Service, Pp. 44. (Stockholm: Swedish Forest Service, 1956.) 